\title{
GEOLOGIC MAP OF THE BROADWELL LAKE QUADRANGLE SAN BERNARDINO COUNTY, CALIFORNIA \\ By
}

T. W. Dibblee, Jr.

MISCELLANEOUS GEOLOGIC INVESTIGATIONS

MAP I-478

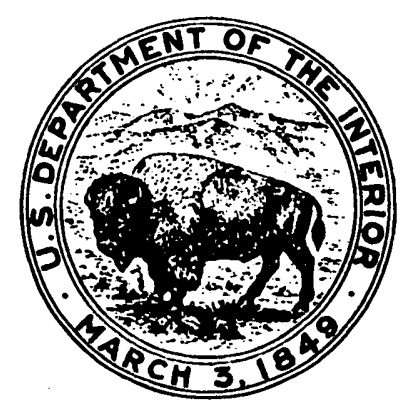




\title{
GEOLOGIC MAP OF THE BROADWELL LAKE QUADRANGLE
} SAN BERNARDINO COUNTY, CALIFORNIA

\author{
By T. W. Dibblee, Jr. \\ DESCRIPTION OF MAP UNITS*
}

\section{CENOZOIC SEDIMENTARY AND VOLCANIC ROCKS}

\author{
Surficial sediments
}

Undissected, unconsolidated sedimentary fill of present valleys and canyons; in valleys presumably as thick as 100 feet, gradational downward into older alluvium; els ewhere unconformable on older formations. Age, very late Pleistocene and Recent. Composed of the following units:

Windblown sand.--Thin cover and elongate dunes of fine sand composed of quartz, feldspar, and mica deposited by prevailing westerly winds on the alluvium and older formations.

Alluvial fan gravel.--Coarse gravel of uns.orted fragments as large as 3 feet in diameter, derived from adjacent mountains and deposited as alluvial fans by runoff from torrential downpours; fragments decrease in size away from mountains and grade downslope into the alluvium. Top surface slopes about 200 feet per mile.

Alluvium.--Gravel composed of small boulders, cobbles and pebbles, and sand, derived from mountains and hills; top surface slopes generally less than 200 feet per mile.

Clay.--Light-gray alkali-rich clay and micaceous silt of Broadwell Lake (usually dry) and dry lake at north edge of quadrangle; top surface level.

\section{Older surficial sediments}

Alluvial gravel and sand derived from adjacent highlands and deposited as alluvial fans by runoff from torrential downpours; now much dissected where elevated. Crudely bedded; maximum exposed thickness about 100 feet. Age, presumably Pleistocene.

Older alluvium.--Gray gravel and sand, grading downslope from boulder gravel to pebbly sand.

Older gravel.--Light-brown cobble-pebble gravel composed mostly of fragments of Tertiary volcanic rocks.

\section{Basalt of Broadwell Mesa}

Black lava that forms Broadwell Mesa, as thick as 100 feet, composed of one or several flows. Basalt black, hard, massive, breaks into large angular blocks; rock finely crystalline to subvitreous, composed of calcic plagioclase, basaltic glass, pyroxene(?), and iron oxides; contains few phenocrysts of olivine; porous, with minute interstitial vugs; generally vesicular, with large vesicules. Unconformable on the older fanglomerate and gravel and on older formations. Referred to by Gardner (1940, p. 286, pl. 11) to Black Mountain Basalt which he bracketed as Pliocene(?) and Pleistocene. Age, presumably Pleistocene.

"Potassic and sodic-calcic (plagioclase) feldspar content of igneous rocks determined by chemical staining of sawed surface of samples by $M$. B. Norman.

\section{Older fanglomerate and gravel}

Weakly consolidated, gray, massive to crudely bedded, coarse gravel derived from nearby mountains and hills; severely dissected; in places deformed. In northern part of quadrangle lowest part includes bedded pebble gravels and sands. Maximum exposed thickness about 150 feet; unconformable on Tertiary formations. Age, presumably Pleistocene.

\section{Rhyolitic tuff}

Light-gray brown-weathering tuff, massive, hard, slightly porous to nonporous and subsiliceous, very fine grained, composed mostly of potassic feldspar, plagioclase, glass(?) and possibly some quartz; contains scattered phenocrysts of iridescent sanidine, plagioclase, and small flakes of biotite. Forms capping layer as thick as 60 feet, on basalt in sec. 2, T. 8 N., R. 9 E.; unconformable on Tertiary volcanic rocks in sec. 11, T. 8 N., R. $9 \mathrm{E}$. Age, presumably Pliocene or Pleistocene.

\section{Basalt}

Black vesicular basalt, similar to the basalt of Broadwell Mesa; maximum exposed thickness about 50 feet. In sec. 2, T. 8 N., R. 9 E., unconformable on Tertiary volcanic rocks and overlain by the rhyolitic tuff; in sec. 22, T. 10 N., R. 7 E., base unexposed, overlain by the Pleistocene older fanglomerate and gravel. Age, presumably Pliocene or Pleis to cene.

\section{Coarse sedimentary rocks}

Coarse fanglomerates and gravels, weakly consolidated, massive to crudely stratified; composed of poorly sorted boulders and cobbles in fragmental to sandy matrix; maximum exposed thickness about 500 feet. Deposited as alluvial fans by runoff from torrential downpours. Unconformable on the underlying Tertiary rock units. Unfossiliferous. Age, presumably Miocene or Pliocene, possibly early Quaternary in Cady Mountains west of T. 10 N., R. 7 E.; unconformably overlies the volcanic and sedimentary rocks that contain middle Miocene (Hemingfordian) fossils (Dibblee and Bassett, 1966): Composed of the following lithogenetic units:

Granitic fanglomerate.--Light-gray fanglomerate predominantly of granitic detritus; most fragments derived from granite, minor amounts derived from biotite quartz diorite.

Volcanic fanglomerate.--Gray fanglomerate of volcanic detritus, derived from andesite and basalt of volcanic and sedimentary rocks and from andesite porphyry of intrusive volcanic rocks.

Andesitic fanglomerate.--Light-brownish-gray fanglomerate mostly derived from andesite and andesite breccia of the volcanic and sedimentary rocks and from andesite porphyry of intrusive volcanic rocks.

\section{Lacustrine sedimentary rocks}

Lacustrine strata near southwest corner of quadrangle; composed of bedded gray limestone or dolo- 
mite, dark chert, thin-bedded siliceous shale, and some ferruginous clay shale; mostly deposited chemically in a lake. Maximum exposed thickness about 60 feet. Unconformable on andesite. Age, probably Miocene, possibly Pliocene.

\section{Intrusive volcanic rocks}

Volcanic rocks occurring as plugs, pods, and dikes intrude pre-Tertiary and Tertiary volcanic and sedimentary rocks; probably fill some vents and fissures through which flows of this assemblage erupted. Age, presumably Tertiary, most likely Oligoc en eor Miocene. Composed of the following units:

Intrusive felsite.--Tan, light-gray to light-pink, flow-laminated to massive rhyolitic felsite; microcrystalline to subvitreous, somewhat porous; composed of plagioclase, potassic feldspar, glass, and small amounts of quartz; locally contains very small phenocrysts of feldspar and flakes of biotite. Flowlaminated rock commonly weathers to platy slabs.

Perlite.--Steel-gray massive perlite with curved fracture. Occurs as a zone as thick as 50 feet at outer margins of intrusive felsite plugs; apparently formed by rapid chilling of felsite magma.

Perlite breccia.--Perlite as described above, but occurs as a large brecciated mass adjacent to a small mass of unbrecciated perlite and rhyolitic felsite about 4 miles north of southeast corner of quadrangle; may be in part extrusive.

Andesite porphyry, intrusive.--Brownish- to greenish-gray massive andesite porphyry composed of abundant phenocrysts (20-45 percent of rock mass) in aphanitic to subvitreous groundmass. Most phenocrysts are plagioclase, few are small biotite plates; groundmass is mostly plagioclase, with small amounts of potassic feldspar and specks of iron oxides.

Andesite porphyry, hydrothermally leached.--Similar to andesite porphyry and gradational into it, but hydrothermally leached to light buff, softer somewhat porous rock in which feldspars (including phenocrysts) are partly altered to kaolinite, and iron content (including that of biotite plates) is largely leached out.

\section{Volcanic and sedimentary rocks}

Assemblage of volcanic flows, pyroclastic rocks, and coarse sedimentary rocks; characterized by extreme lenticularity and intergradation of lithologic units. Maximum exposed thickness of assemblage about 5,000 feet; rests unconformably on uneven surface of pre-Tertiary crystalline rocks. Unfossiliferous. Age, Tertiary, probably Oligocene or early Miocene, or possibly older, on basis of stratigraphic position below sedimentary rocks that contain middle Miocene vertebrate fossils west of quadrangle (Bassett and Kupfer, 1964, p. 22; Dibblee and Bassett, 1966). Composed of the following lithologic units:

Fanglomerate of dioritic detritus.--Gray, unstratified, weakly consolidated fanglomerate or gravel composed of unsorted, subrounded fragments as large as 2 feet in diameter mostly of the pre-Tertiary hornblende diorite-gabbro and biotite quartz diorite, some of granite and Tertiary andesite and basalt, in coarse sandy matrix.

Fanglomerate of granitic detritus.--Similar to fanglomerate described above, but buff colored and fragments mostly of granite, some of biotite quartz diorite and Tertiary andesite, in coarse arkosic matrix.

Fanglomerate of andesitic detritus.--Similar to fanglomerates described above, but light-brown, and fragments mostly of Tertiary andesite and andesite porphyry, in matrix of coarse andesitic sand.
Fanglomerate of basaltic detritus.--Similar to fanglomerates described above, but dark-gray to nearly black, and fragments mostly of Tertiary bas alt or basalt porphyry, in matrix of basaltic sand.

Basalt.--Dark-gray to black, massive, finely crystalline, composed of gray calcic plagioclase, basaltic glass, pyroxene, olivine, and finely divided magnetite; in places contains small phenocrysts of olivine; less commonly of calcic plagioclase; commonly contains amygdules of calcite, quartz, chalcedony, and opal, and locally contains veinlets of same minerals. Commonly with subplaty fracture, generally parallel to top or base of flows.

Basalt breccia.--Dark-gray to black, massive, composed of unsorted subangular fragments as large as 3 feet in diameter of black porphyritic basalt in fragmental basalt matrix. Probably deposited as flow breccia or as basalt fanglomerate.

Andesite.--Greenish-gray, brown to dark-reddishbrown; massive, aphanitic to porphyritic; composed mostly of plagioclase; little or no potassic feldspar; specks of iron oxides; phenocrysts mostly of plagioclase. Forms thick flows. In Cady Mountains much of andesite is aphanitic with subplaty fracture generally parallel to top or base of flows. Gradational into the andesite breccia.

Andesite breccia.--Same as andesite described above, but severely brecciated, unlayered. Forms thick flow breccias. Gradational into the fanglomerate of andesitic detritus and into the tuff breccia.

Tuff breccia.--Light-colored tuffaceous rocks that range from nearly white, poorly bedded, tuff breccia composed of small white fragments of devitrified andesitic glass or of pumice in tuffaceous matrix to massive or crudely bedded buff to greenish-tan tuffaceous breccia or agglomerate composed of poorly sorted angular to subrounded andesitic fragments nearly as large as a foot in diameter embedded in tuffaceous sandstone. Deposited as volcanic mud flows and ash.

Tuffaceous sandstone.--In Broadwell Mesa area white to light-green, bedded, fine- to coarse-grained tuffaceous sandstone and some intercalations of white tuff and andesitic pebble conglomerate.

Sandstone.--Light-gray to reddish-buff, bedded, fine- to coarse-grained arkosic sandstone and some interbedded granitic conglomerate at point 3 miles west of Broadwell site; red arkosic sandstone near southwest corner of quadrangle.

Granitic breccia.--Light-buff massive breccia of granitic aplite. Occurs as a thin landslide breccia in tuffaceous sands tone.

Rhyolitic felsite.--Rock similar in color, texture, and composition to intrusive felsite described above; massive to faintly flow-laminated; in places brecciated. Forms short, thick, lenticular flows, but may be in part intrusive.

\section{MESOZOIC AND OLDER(?) PLUTONIC IGNEOUS ROCKS}

\section{Quartz monzonite}

Nearly white massive coarse-grained granitic rock composed of quartz, potassic feldspar, and plagioclase (oligoclase) in nearly equal proportions, about 5 percent biotite (as euhedral plates) and about 1 percent accessories (hornblende, sphene, zircon, apatite, and magnetite). Rock incoherent where weathered; breaks down into its constituent grains. Rarely, porphyritic; with or thoclase phenocrysts. Youngest of plutonic rock as indicated by intrusive relations with other preTertiary rocks in areas outside of quadrangle. Age, Mesozoic, most likely Cretaceous. 


\section{Granite}

Light gray and buff to nearly white, hard granitic rock; predominantly medium-grained, but in places fine-grained; composed of about one-third quartz, two thirds feldspar, and about 1 percent accessories (biotite, muscovite, sphene, zircon, and magnetite). In most places feldspar is predominantly microcline-perthite or orthoclase; remainder is plagioclase (albite-oligoclase). In some places all feldspar is microclineperthite; in others, nearly half is plagioclase. Rock generally equigranular, massive, rarely faintly gneissoid. In places slightly iron-stained. Intrusive into metamorphic and other plutonic rocks except the quartz monzonite. Age, presumably Mesozoic.

\section{Granite-migmatite complex}

Similar to granite described above, but medium- to fine-grained, and contains some admixtures of contorted migmatite and gneiss. Age, presumably Mesozoic, possibly in part older.

\section{Hornblende diorite-gabbro}

Dark-gray to black, medium- to coarse-grained, massive dioritic rock composed mostly of hornblende or biotite and calcic plagioclase; small amounts of hypersthene and magnetite; in places, some epidote and chlorite. Forms masses engulfed in the granite. Age, Mesozoic, possibly older.

\section{Quartz diorite porphyry}

Gray, massive to gneissoid, porphyritic, mediumto coarse-grained granitic rock composed of quartz, potassic feldspar, and plagioclase (oligoclase) with plagioclase predominant, about 15 percent biotite (as streaks of numerous minute flakes), about 2 percent accessories (hornblende, sphene, and magnetite), and scattered to abundant large phenocrysts or porphyroblasts as long as 1 inch of potassic feldspar (orthoclase). Either crystallized from magma or possibly recrystallized from gneiss or schist. Age, Mesozoic or older.

\section{Biotite quartz diorite}

Dark-gray, medium- to fine-grained, massive to gneissoid or weakly foliated dioritic rock of variable composition. Composed of nearly two-thirds plagioclase, one-fourth to one-third biotite, and minor amounts of quartz, potassic feldspar, hornblende, and iron oxides. In places rock contains no quartz, in others, almost no potassic feldspar. Either crystallized from a magma or recrystallized from gneiss or schist. Occurs as elongate pendants engulfed in the granite. Age, Mesozoic or older.

\section{PRE-MESOZOIC METAMORPHIC ROCKS Marble}

White to gray-white, medium to coarsely crystalline marble; poorly bedded to massive. Occurs as pendants in biotite quartz diorite or granite. In a few places, contact partly silicated to garnet-epidote tactite a few inches wide. Age, probably Paleozoic, possibly older.

\section{Gneiss}

Gray banded gneiss composed of quartz, potassic feldspar, plagioclase, and biotite in variable amounts and less than 1 percent hornblende and iron oxides. Rock composed of white bands rich in quartz and feldspar alternating with black bands rich in biotite and gray bands of intermediate composition. Biotite oriented parallel to banding. Age, probably Precambrian, possibly Paleozoic.

\section{MINES AND PROSPECTS}

\section{Manganese}

A. Lavic Mountain (Lee Yim) mine. Ten claims in NE $\frac{1}{4}$ sec. 27, SE $\frac{1}{4}$ sec. 22, T. 8 N., R. 7 E. Manganese oxides, with calcite, hematite, and jasper, in brecciated zones in aphanitic andesite. Main zone, as long as 2,300 feet, strikes $\mathrm{N}$. $45^{\circ} \mathrm{W}$, dips $70^{\circ}-85^{\circ} \mathrm{NE}$; as wide as 30 feet, but in most places only 2 or 3 feet wide; several other minor parallel zones within 250 feet to NE. Main zone has smooth footwall and gradational hanging wall; developed by adit driven about 60 feet southeast from south side of canyon and open-cut uphill to southeast. About 100 tons of ore averaging 38 percent manganese shipped during World War I. Prior to 1942 , main zone and other minor zones prospected by several shallow shafts, drifts, and open cuts, but no ore shipped; now idle (Wright and others, 1953, p. 115).

B. Manganese prospect. SE $\frac{1}{4}$ sec. 12, T. 8 N., R. 7 E. Manganese oxides with calcite in zone of fault breccia as wide as 20 feet, strikes N. $30^{\circ} \mathrm{W}$., vertical, between andesite to southwest and volcanic fanglomerate to northeast. Prospected by two adits driven northeast, one 30 feet long, the other 15 feet long. Long idle.

\section{Gold-copper}

C. Old Dominion mine. NW $\frac{1}{4}$ sec. 23, T. 9 N., R. 7 E., Blue chrysocolla coatings along shear zone in hornblende diorite-gabbro pendant in granite. Prospected by shallow shaft. Long idle.

D. Prospect in NW $\frac{1}{4}$ sec. 15, T. 9 N., R. 8 E. Thin quartz veins in granite. Prospected by shallow shaft and open cuts. Long idle.

E. Prospect in $W \frac{1}{2}$ sec. 2, T. 10 N., R. 9 E. Sulfides in quartz along shear zones, strikes east, in gneiss. Prospected by short tunnel driven north andopen cuts. Long idle.

F. Prospect in sec. 23, T. 10 N., R. 9 E. Sulfides in quartz along shear zones in hornblende diorite gabbro pendant in granite. Prospected by shaft about 50 feet deep at edge of quadrangle. Shaft to southwest about 20 feet deep in alluvium. Long idle.

\section{Perlite}

G. Perlite prospect. NW $\frac{1}{4}$ sec. 24, T. 9 N., R. 8 E. Perlite zone about 50 feet wide, along outer margin of intrusive felsite cutting tuff breccia. Small tonnage quarried prior to 1955 from small open cut.

\section{REFERENCES}

Bassett, A. M., and Kupfer, D. H., 1964, A geologic reconnaissance in the southeastern Mojave Desert, California; California Div. Mines and GeologySpec. Rept. 83, 43 p., map.

Dibblee, T. W., Jr., and Bassett, A. M., 1966, Geologic map of the Cady Mountains quadrangle, San Bernardino County, California: U.S. Geol. Survey Misc. Geol. Inv. Map I-467, scale 1:62,500.

Gardner, D. L., 1940, Geology of the Newberry and Ord Mountains: California Jour. Mines and Geology, v. 36, no. 3 , p. 257-292, pl. 11 .

Wright, L. A., Stewart, R. M., Gay, T. E., Jr., and Hazenbush, G. C., 1953, Mines and mineral deposits of San Bernardino County, California: California Jour. Mines and Geology, v. 49, nos. 1-2, p. 49257, with tabulated list, $192 \mathrm{p}$. 